\title{
Characterization of Antimycins - Producing Streptomycete Strain VY46 Isolated from Slovak Soil
}

\author{
Ivana Charousová $^{1 *}$, Heinrich Steinmetz ${ }^{2}$, Juraj Medo ${ }^{1}$, Sona Javoreková ${ }^{1}$, Joachim \\ Wink $^{2}$. \\ ${ }^{1}$ Slovenska Polnohospodarska Univerzita, Department of Microbiology, Nitra, Slovakia; ${ }^{2}$ Helmholtz-Zentrum fur \\ Infektionsforschung GMh, Braunschweig, Niedersachsen, Germany.
}

\begin{abstract}
The strain no. VY46 was isolated from agricultural soil of Slovak republic and tested for potential antimicrobial activity against various human pathogens. On the basis of results, strain VY46 significantly inhibited growth of yeast Candida albicans and therefore was used for further characterization. In order to explore the potential bioactivities, extract of the fermented broth culture was prepared with organic solvent extraction method. The ethylacetate extract was subjected to HPLC fractionation against Candida albicans and followed by LC/MS analysis for potential production of anticandidal substances. The analysis resulted in the identification of two antimycins antibiotics, which may be responsible for important anticandidal activity of the strain. On the basis of liquid chromatography and mass spectrometry the antibiotics were identified as Urauchimycin A and Kitamycin A. According tothe results from cultural, morphological, physiological, biochemical and 16S rRNA gene sequence methods, the strain was identified as Streptomyces albidoflavus. In addition, neighbor-joining phylogenetic tree confirmed the relationships of this strain to other members of Streptomyces genera.
\end{abstract}

Key words:Streptomycetes, anticandidal activity, metabolite production, antimycins antibiotics

\footnotetext{
*Authors for correspondence: ivanacharousova@gmail.com
} 


\section{INTRODUCTION}

Soil microorganisms provide an excellent resource for the isolation and identification of therapeutically important products. Among them, actinomycetes, particularly members of the genus Streptomyces, are an important group of filamentous, gram-positive bacteria producing antibiotics of medical importance ${ }^{1}$. The number of antimicrobial compounds reported from the species of this genus per year has increased almost exponentially for about two decades ${ }^{2}$. Up to this date, more than 10,000 antibiotics have been isolated from actinomycetes ${ }^{3}$.

Among the different types of drugs prevailing on the market, antifungal antibiotics are a very few but vital group of drugsand they have an important role in the control of mycotic diseases ${ }^{4}$. Candida albicans is the most important and frequent fungal opportunistic pathogen 5. However, many of infections due to Candida species are refractory to antifungal therapy ${ }^{6}$, because of resistance to antifungal metabolites, toxicity, drug interactions and expense ${ }^{7}$. In clinical settings, candidiasis are commonly treated with antimycotics and other antifungal drugs commonly used to treat candidiasis $^{8}$.

The antimycins are forming a group of about 30 closely related lactolide antibiotics ${ }^{9}$. The antimycins differ in the nature of their alkyl residue at C-7 and of the oxygen substituent at C8: Acylation of the 8-hydroxy group modulates the strong antifungal,

antiviral and antitumor activities ${ }^{10}$.Production of antimycinantibiotics were confirmed in differentstreptomycete strains ${ }^{11,12,13}$.

Therefore, the present study is intended to isolate, screen antimicrobial potential against pathogens and characterize streptomycete strain VY46, which produce antimycins antibiotics active against yeast Candida albicans.

\section{MATERIAL AND METHODS}

\section{Isolation and Maintenance of the Isolate}

Streptomycete strain VY46 was preliminary identified according to the method described by Bergey's Manual of Determinative Bacteriology ${ }^{14}$. Strain VY46 was isolated from a soil sample identified asa haplic fluvisol taken from growing area of Agrokomplex located in Nitra, Slovakia. A 5 gof the pretreated air-dried soil was mixed with
$45 \mathrm{ml}$ of sterilized water and spread onto the isolation Pochon medium ${ }^{15}$ supplemented with nystatin $\left(50 \mu \mathrm{g} \cdot \mathrm{ml}^{-1}\right)$ and incubated at $28{ }^{\circ} \mathrm{C}$ for 14 days. Pure cultures of strain VY46 were isolated, re-cultivated several times for purity on GYM medium ${ }^{16}$ and maintained as glycerol suspensions $(20 \%, \mathrm{v} / \mathrm{v})$ at $-20{ }^{\circ} \mathrm{C}$ for long term preservation.

\section{Screening of Antimicrobial Activity}

The strain VY46 was inoculated in liquid 5294, 5254 and $5333{ }^{17}$ media and incubated for 7 days at $28{ }^{\circ} \mathrm{C}$ in incubator shaker. The isolate was screened against Escherichia coli (DSM 116), Escherichia coli WT3 (resistance on chinolone), Staphylococcus aureus (Newman), Staphylococcus aureus N315 (MRSA), Candida albicans (DSM 1665), Pseudomonas aeruginosa (DSM 19882), Enterococcus faecium (DSM 20477) and Enterococcus faecium (DSM 17050). Tested strains wereobtained from Microbial Strain Collection Group (MISG) of Helmholtz Centrum for Infection Research (HZI) in Braunschweig, Germany. A 20 mlof 5 days old culture were mixed with $20 \mathrm{ml}$ of ethyl acetate (Sigma Aldrich, USA). After a shaking step the sample was centrifuged at $9000 \mathrm{rpm}$ for $10 \mathrm{~min}$ and the upper phase was transferred into a $50 \mathrm{ml}$ round bottom flask. At about $40^{\circ} \mathrm{C}$ the ethyl acetate was evaporated in a rotary evaporator (Heidolph, Germany). Finally, the extract wasdissolved in 1 $\mathrm{ml}$ of ethyl acetate: acetone: methanol $(1: 1: 1)$ solution. Determination of MIC values were carried out by preparing 4-6 h cultures of indicator bacteria followed by dilution with Mueller- Hinton (MH) broth (Merck, Germany) to obtain 0.05 McFarland standard turbidity and 4-6 h culture of yeast by dilution on Mycosel broth ${ }^{18}$ to obtain 0.01 McFarland turbidity. Minimal inhibition concentration (MIC) was determined by using the broth microdilution method ${ }^{19}$ in 96- well microplates (BRAND, Germany). The MIC values were defined as the lowest concentration of the tested extract that visible growth of test microorganisms was not observed. MIC determination was prepared using twofold serial dilutions in MH/MYC broth to obtain a concentration ranging of 300-0.16 $\mu \mathrm{g}-\mathrm{ml}^{-1}$.

\section{Metabolite Identification}

Ethylacetate extract was fractionated using HPLC Agilent 1100 equipment with an analytical column

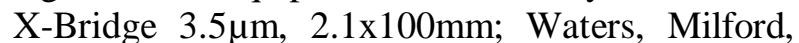
USA. HPLC separations used $\mathrm{H} 2 \mathrm{O}+0.05 \mathrm{mM}$ 
ammonium acetate buffer (pH 5) (A) and acetonitrile $+0.05 \mathrm{mM}$ ammonium acetate buffer (pH 5) (B) at a flow rate of $0.3 \mathrm{ml} \cdot \mathrm{min}^{-1}$ and a DAD detector $(200-400 \mathrm{~nm})$. Fractions $(0.15 \mathrm{ml})$ from the HPLC column were collected in a 96well plates every $0.5 \mathrm{~min}$. The fractions in the 96 well plate were dried for $45-60 \mathrm{~min}$. at $40{ }^{\circ} \mathrm{C}$ with heated nitrogen in MiniVap (Porvair Sciences, UK). Afterwards, each well was filled with $5 \mu$ l of DMSO and $150 \mu 1$ of the yeast Candida albicans in MYC medium.

The extract was applied to an LC-MS system, which consisted of an HPLC system Agilent 1200 series with DAD detector (200-600nm) in connection with a maXis UHR-TOF mass spectrometer (Bruker Daltonics, USA). Samples were analyzed using a Waters ACQUITY UPLC BEH C18 Column, 2.1 x $50 \mathrm{~mm}, 1.7 \mu \mathrm{m}$.

The conditions of LC/MS system included the following: the mobile phase consisting of gradient elution utilized $\mathrm{H}_{2} \mathrm{O}$ with $0.1 \%$ formic acid as solvent $\mathrm{A}$ and $\mathrm{CH}_{3} \mathrm{CN}$ with $0.1 \%$ formic acid as solvent $\mathrm{B}$ at a flow rate of $0.6 \mathrm{ml}-\mathrm{min}^{-1}$. The gradient was as follows: $0.5 \mathrm{~min} 5 \% \mathrm{~B}, 19.5 \mathrm{~min}$ $95 \% \mathrm{~B}$ and $10 \mathrm{~min} 95 \% \mathrm{~B}$. The column temperature was maintained at $40{ }^{\circ} \mathrm{C}$.

Active compounds were identified by comparison of molecular weights, UV spectra, and retention times with authentic standards. The main software for processing of results was Data Analysis included in the Compass-software from Bruker (USA).

\section{Characterization of Streptomyces Isolate VY46}

\section{Cultural and Micro-Morphological} Characteristics

The cultural features of the strain were characterized following the directions given by the International Streptomyces Project (ISP) ${ }^{20}$ media, namelyyeast- malt agar (ISP2), oatmeal agar (ISP3), inorganic salt-starch agar (ISP4), glycerol asparagine agar (ISP5), peptone yeast extract iron agar (ISP6) and tyrosine agar (ISP7). For morphological characteristic, four parameters were used - growth, reverse colors, colors of aerial mycelium and colors of soluble pigments. Melanin pigment production was determined by growth on ISP6 and ISP7 media together with the synthetically Sutermedium ${ }^{21}$ with and without tyrosine. For the light microscopic classification of the strain, well grown agar plate with GYM medium was used for observation of spore chain morphology.

\section{Physiological and Biochemical Characteristics}

The physiological testing included $\mathrm{pH}$ tolerance that was tested in tubes with liquid ISP2 medium at $\mathrm{pH}$ levels of $2,3,4,5,6,7,8,9$, and 10 . For determination of optimal temperature ISP2 agar plates were incubated at $4,25,28,30,37$ and 42 ${ }^{\circ} \mathrm{C}$. Sodium chloride tolerance was tested on microtiter plates (six-well) using a technique based on the method of $^{22}$.Utilization of 10 different carbon sources was determined on the basis of ${ }^{20}$ methodology using a microplate technique with twelve well plates. Commercially available test kits such as ApiZym $^{\circledR}$ and ApiCoryne ${ }^{\circledR}$ (bioMérieux, France) were used for biochemical characteristic of the strain. Api stripes were inoculated followed by manufacturer's manual.

\section{Extraction of the Genomic DNA, PCR Reaction} and Sequencing of $16 S$ rRNA Gene

Genomic DNA was isolated according to ${ }^{23}$ methodology. The isolated DNA was amplified by PCR reaction using primers according to ${ }^{24}$. Reaction mixture was made in total volume of 50 $\mu 1$. Each reaction contained $5 \mu$ of $10 \times$ DreamTaq Green PCR buffer, $5 \mu \mathrm{l}$ of 2 mmol.dm ${ }^{-3} \mathrm{dNTP}, 2 \mu \mathrm{l}$ of each $10 \mu \mathrm{mol} . \mathrm{dm}^{-3}$ primer, $0.3 \mu \mathrm{lTaq}$ DNA polymerase and $0.5 \mu \mathrm{l}$ of template DNA (approximately $20 \mathrm{ng}$ ). The PCR reaction ran in thermo cycler Biometra $\mathrm{T}$ Personal under the following conditions: $95^{\circ} \mathrm{C}$ for $3 \mathrm{~min}, 40$ cycles of $95{ }^{\circ} \mathrm{C}$ for $30 \mathrm{sec}, 56{ }^{\circ} \mathrm{C}$ for $30 \mathrm{sec}, 72{ }^{\circ} \mathrm{C}$ for 90 sec and final extension at $72{ }^{\circ} \mathrm{C}$ for $10 \mathrm{~min}$. The purified PCR product was sequenced inMacroGen Genomics, Korea. The 16S rRNA gene sequence was compared with sequences obtained from GenBank. Multiple alignments of the sequences were performed using ClustalW ${ }^{25}$ and gaps and unidentified base positions were edited using BioEdit $^{26}$. Phylogenetic trees were constructed with the Maximum- Likelihood method ${ }^{27}$ using PhyML $^{28}$, with bootstrap values based on the 100 replications.

\section{RESULTS AND DISCUSSION}

\section{Antimicrobial Activity and Bioactive Compounds of the Strain VY46}

The MIC values for antimicrobial activity of the tested strain are given in Table 1 . The results 
revealed that extract (obtained from 5254 medium) exhibited the strongest antimicrobial activity against yeast Candida albicans (DSM 1665) with a MIC equal to $0,625 \mu \mathrm{g} \cdot \mathrm{ml}^{-1}$ and therefore the extract was subjected to HPLC fractionation against Candida albicans followed by LC/MS analysis of active compounds.

Table 1 - Antimicrobial activity of strain VY46 against human pathogens

\begin{tabular}{|c|c|c|c|c|c|c|c|c|}
\hline \multirow[b]{2}{*}{ Med. } & \multicolumn{8}{|c|}{ MIC $\left(\mu \mathrm{g} . \mathrm{ml}^{-1}\right)$} \\
\hline & $\begin{array}{l}\text { E. coli } \\
\text { DSM11 } \\
6\end{array}$ & $\begin{array}{l}\text { E. coli } \\
\text { WT3 }\end{array}$ & $\begin{array}{l}\text { S.aureu } \\
s \\
\text { Newma } \\
\mathrm{n}\end{array}$ & $\begin{array}{l}\text { S.aureu } \\
s \\
\text { N315 }\end{array}$ & $\begin{array}{l}\text { C.albican } \\
S \\
\text { DSM166 } \\
5\end{array}$ & $\begin{array}{l}\text { P.aeruginos } \\
a \\
\text { DSM19882 }\end{array}$ & $\begin{array}{l}\text { E. faecium } \\
\text { DSM2047 } \\
7\end{array}$ & $\begin{array}{l}\text { E. faecium } \\
\text { DSM1705 } \\
0\end{array}$ \\
\hline 5294 & 20 & 20 & 5 & 2,5 & 1,25 & 20 & 5 & 10 \\
\hline 5254 & 20 & 20 & 2,5 & 2,5 & 0,625 & 20 & 5 & 5 \\
\hline 5333 & 10 & 10 & 2,5 & 2,5 & 1,25 & 20 & 10 & 5 \\
\hline
\end{tabular}

Chromatographic procedures revealed that ethylacetate extract from strain VY46 contains two active compounds active against Candida albicans(Fig. 1).

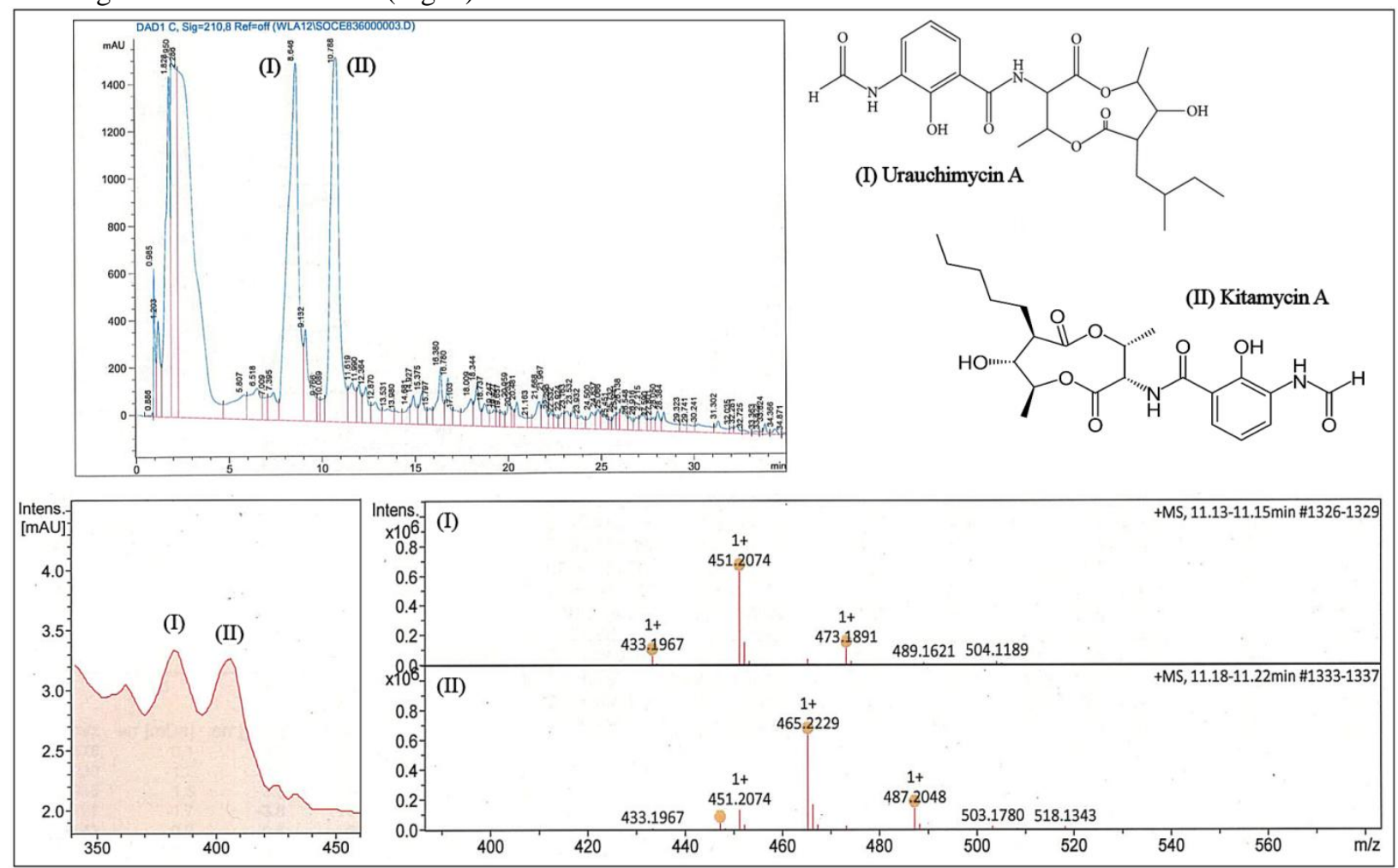

Fig. 1 Identification of active metabolites from strain VY46. (a) HPLC profile of ethylacetate extract from culture, with analysed peaks labelled as (I) and (II). (b) UV-VIS and MS spectra of (I) and (II)

The anticandidal activity test applied to all HPLC fractions showed that the peaks around retention 8.0 and $11.0 \mathrm{~min}$ contained the active fractions.LC/MS analysis, which led to the identification of two active peaks eluting at 11.13$11.15 \mathrm{~min}$ and $11.18-11.22 \mathrm{~min}$, containing the major anticandidal activity. These peaks exhibited UV-VIS maxima at $380 \mathrm{~nm}$ and showed $\mathrm{M}^{+} \mathrm{H}^{+}$of 433.1969, 451.2075 and $473.1894 \mathrm{~m} / \mathrm{z}$, respectively and at $400 \mathrm{~nm}$, which showed $\mathrm{M}^{+} \mathrm{H}^{+}$ of 447.2126, 465.2231 and 487.2051 m/z, respectively. The chromatographic separation and mass spectrophotometer detection provided a large number of fragmentation pattern. Analysis can use ESI positive and negative charges. The negative ESI mode is characterized by the formation of the $\mathrm{M}-\mathrm{H}^{-}$ion, and the positive ESI mode is characterized by the formation of the $\mathrm{M}^{+} \mathrm{H}^{+}$ion. This experiment used positive ESI. HPLC coupled with LC/MS is one of the most powerful tools for detecting bioactive compounds from microorganisms ${ }^{29}$. According to used software we 
identified active compounds by comparison of molecular weights, UV spectra, and retention times like Urauchimycin A and Kitamycin A.

Kitamycin A and Urauchimycin A belong to the antimycin class, a group of well-known antifungals. Antimycins act by inhibiting the electron flow in the mitochondrial respiratory chain (Barrow et al. 1997). Urauchimycins A and B were previously isolated from Streptomyces sp. $\mathrm{Ni}-80$ isolated from a marine sponge in Urauchicove, Irimore, Japan. These substances were the first antimycins having an odd number of carbons and a branching side chain ${ }^{30}$. In 2006, two new urauchimycins were described: urauchimycin C, isolated from Streptomyces sp. B1751 from marine sediment, and urauchimycin D, isolated from Streptomyces sp. AdM21 from soil ${ }^{31}$. In the study by ${ }^{30}$ the urauchimycins $A$ and B inhibited the morphological differentiation of $C$. albicans up to a concentration $10 \mu \mathrm{g} \cdot \mathrm{ml}^{-1}$. There is only one mentionabout isolation and identification of Kitamycin produced by Streptomyces sp. ${ }^{32}$. There is no report about production of Urauchimycin A and Kitamycin A by soil streptomyceteS. albidoflavus.

\section{Characterization of Strain VY46}

Actinomycete taxonomy was formerly thought to be associated with morphology, which is inadequate in differentiating between different species of many genera. Recently, the identification of the species and phylogenies are commonly derived from 16S rDNA and the use of polymerase chain reaction (PCR) for sequence analyses ${ }^{33},{ }^{34}$. Comparison of the $16 \mathrm{~S}$ rDNA sequences of strain VY46 with the GenBank database showed that this isolate belongs to the genus Streptomyces(Fig. 2).

Results obtained from $16 \mathrm{~S}$ rRNAshowed the highest similarity with $S$. albidoflavus. This conclusion was confirmed by morphological and physiological identification. According to $16 \mathrm{~S}$ rRNA sequences obtained from BLAST search, the most similar strains were compared with strain no. VY46.

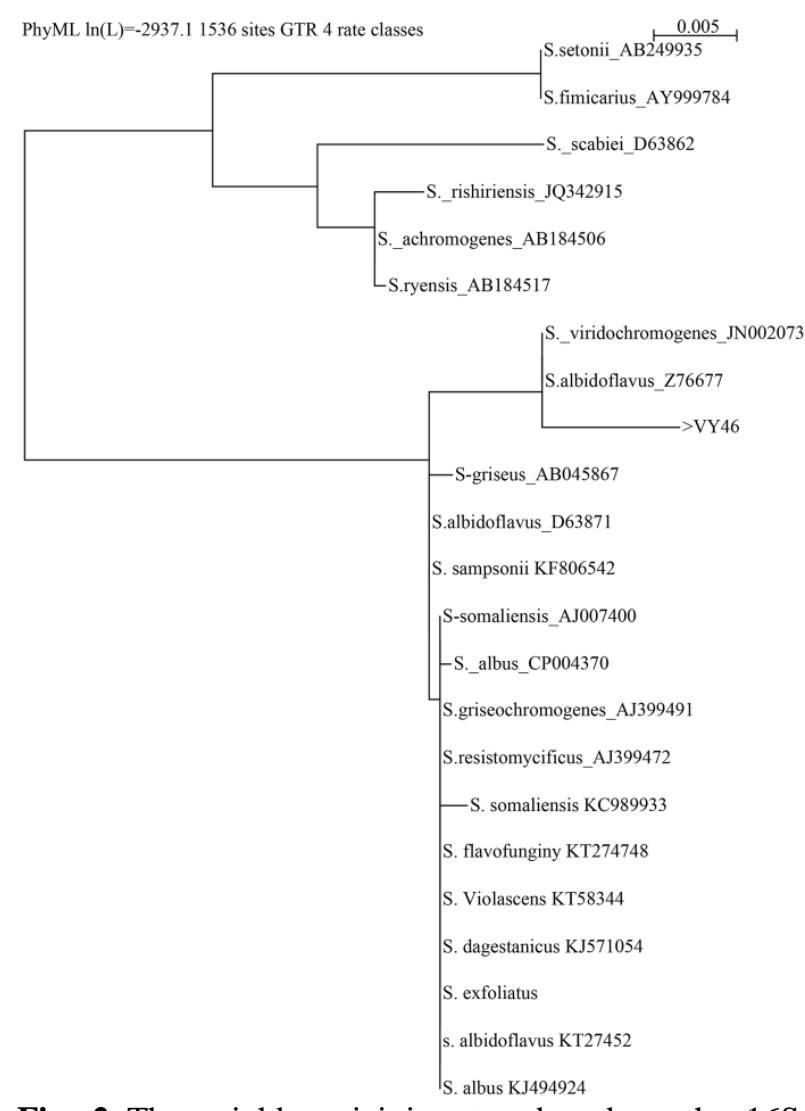

Fig. 2 The neighbour-joining tree based on the $16 \mathrm{~S}$ rRNA gene sequences

The isolate was aerobic, and exhibited typical morphological characteristics of the genus Streptomyces (chalky, heaped and folded colony with aerial and substrate mycelium possessed an earthy odor) ${ }^{35}$.Strain VY 46 produced sparse aerial mycelium that displayed a tendency to fragment with aging of the culture. The hyphae of the substrate mycelium were branching, penetrating into the agar medium, forming fastgrowing, spreading colonies. The observation with light microscopy after Gram staining indicated that the strain was a Gram positive, with the sporebearing hyphae Rectus flexibilis. During the culture growth, green beige pigment diffused into the surrounding medium. Melanoid pigment was produced only on Suter medium with addition of tyrosine.

Growth of the strain VY46 occurred in the $\mathrm{pH}$ range of 6-9 with optimum growth at $\mathrm{pH} 7$. The temperature range for growth was $25-37{ }^{\circ} \mathrm{C}$ with the optimum temperature being $28{ }^{\circ} \mathrm{C}$.The strain exhibited salt tolerance up to $7.5 \%$ with optimum growth at $2.5 \% \mathrm{NaCl}$, hence, the strain could be placed in intermediate salt tolerance group according to ${ }^{36}$. Carbohydrate utilization test played 
a prominent role in the taxonomic characterization of the strains. Studies on the requirement of carbon sources for growth showed that tested strain could utilize glucose, arabinose, mannose and cellulose. Characterization of the selected strainswere described in Bergye'sManual of Systematic
Bacteriology ${ }^{20}$, Compendium of Actinobacteria from Dr. Joachim M. Wink, University of Braunschweig, Germany and ${ }^{37}$ (Table 2).

Table 2 -Morphological and physiological characteristic of strain VY46 and phylogenetically related Streptomyces species

\begin{tabular}{llllllll}
\hline \multirow{2}{*}{$\begin{array}{l}\text { Characteristi } \\
\text { c }\end{array}$} & \multicolumn{2}{l}{ Streptomyces strains } & \multicolumn{7}{l}{} \\
\cline { 2 - 9 } & VY46 & $\mathbf{1}$ & $\mathbf{2}$ & $\mathbf{3}$ & $\mathbf{4}$ & $\mathbf{5}$ & $\mathbf{6}$ \\
\hline Spore chain & RF & RF & RF & very short & ND & RF & RF \\
\hline Aerial mass colour & & & & & & \\
\hline ISP2 & white & white & white & none & cream & white & white \\
ISP3 & sparse & sparse & white & white & cream & white & ivory \\
ISP4 & white & white & white & white & cream & white & white \\
ISP5 & white & white & white & none & sparse & white & white \\
ISP6 & white & white & white & none & light grey & ND & ND \\
ISP7 & white & white & white & white & sparse & ND & ND \\
\hline Reverse side colour & & & & & & \\
\hline ISP2 & colourles & colourless & brown & yellow & brown & yellow & yellow \\
& s & & & & & & \\
ISP3 & brown & colourless & brown & colourless & brown & yellow & ivory \\
ISP4 & yellow & colourless & brown & yellow & brown & ivory & yellow \\
ISP5 & yellow & colourless & reddish & yellow & yellow & yellow & yellow \\
ISP6 & brown & brown & red & yellow & yellow & ND & ND \\
ISP7 & colourles & colourless & reddish & yellow & yellow & ND & ND
\end{tabular}

\begin{tabular}{|c|c|c|c|c|c|c|c|}
\hline \multicolumn{8}{|c|}{$\mathrm{S}$} \\
\hline Melanine & + & - & + & + & - & - & + \\
\hline \multicolumn{8}{|c|}{ Growth on sole carbon sources } \\
\hline Glucose & + & + & + & + & + & + & + \\
\hline Arabinose & + & - & - & - & + & - & + \\
\hline Sucrose & - & - & + & - & + & - & - \\
\hline Xylose & - & - & + & - & + & + & - \\
\hline Inositol & - & - & - & - & + & - & - \\
\hline Mannose & + & - & + & + & + & + & + \\
\hline Fructose & - & - & + & + & + & + & + \\
\hline Rhamnose & - & - & - & - & + & - & - \\
\hline Raffinose & - & - & + & - & + & - & - \\
\hline Cellulose & + & - & - & + & + & - & - \\
\hline $\begin{array}{l}\text { NaCltoleranc } \\
\text { e }\end{array}$ & 7.5 & 7.5 & 5 & 5 & ND & 2.5 & 7.5 \\
\hline Temperature & 28 & 30 & 28 & 28 & 28 & 30 & 30 \\
\hline
\end{tabular}

Strains/species: 1. Streptomyces albidoflavus, 2. Streptomyces exfoliatus, 3. Streptomyces flavofungini, 4. Streptomyces daghestanicus, 5. Streptomyces albus, 6. Streptomyces sampsonii. RF-Rectus flexibilis, + positive, negative, ND-No data available

Morphological and physiological parameters confirmed results from $16 \mathrm{~S}$ rRNA analysis and also indicated that the strain VY46 is the most similar to $S$. albidoflavus.

The actinomycetes are considered as the main group of soil microorganisms that play a major role in recycling of organic matters in environment by production of hydrolytic enzymes ${ }^{38}$. The API ZYM and API-CORYNE systems offer a useful method for detection of selected enzymes in Streptomyces species ${ }^{39}$. According to the results, positive reaction was determined for 
alkalinephosphatase (level 5), esterase (level 3), esterase-lipase (level 4), lipase (level 3), leucinearylamidase (level 5), valinearylamidase (level 3), phosphatase acid (level 3), naphtol-ASBI-phosphohydrolase (level 5), glucosidase (level 3) with 2-naphtyl-D-glucopyranoside substrate, glucosidase (level 5) with 6-Br-2-naphtyl-Dglucopyranoside as substrate, N-acetyl glucoseamidase (level 5), nitrate reduction and gelatine hydrolysis. Fermentations tests were negative. According to ${ }^{40}$ common enzymes found at all streptomycete strains were also leucinarylamidase and acid phosphatase and $89 \%$ of strains showed activity of valinearylamidase. Contrary, the least occurring enzyme was $\beta$ glucuronidase like in our study. Color intensity of trypsin, cystinearylamidase, chymotrypsin, galactosidase, mannosidase and fucosidase were very low.

\section{CONCLUSION}

In this study, streptomycete strain VY46 was isolated from soil collected in Slovakia. On the basis of morphological, physiological, biochemical and 16S rRNA gene sequence, this strain was identified asS. albidoflavus. Antimicrobial assay indicated that this strain was highly active against yeast Candida albicans. HPLC and LC/MS analysis of extract led to identification of two antimycin antibiotics - Kitamycin A and Urauchimycin A. There is no report about production of antimycin antibiotics by Streptomyces albidoflavus until now and therefore the strain VY46 can be considered as a potential new source of antimycin antibiotics and can be promising candidate for further screening.

\section{ACKNOWLEDGMENTS}

The author is grateful to Helmholtz Centrum for Infection Research (Microbial Strain Collection Group), Braunschweig, Germany for the scholarship and supporting of the results. This study was also supported by Europien Community under project no. 26220220180: Building Research Centre Agrobiotech.Special thanks to Ing. Milan Adamec for corrections of English grammar.

\section{REFERENCES}

1-Berdy J. Bioactive microbial metabolites. $J$ Antibiot. 2005; 58:1-26.

2-Watve MG, Tickoo R, Jog MM, Bhole BD. How many antibiotics are produced by the genus Streptomyces.Arch Microbiol. 2001; 176: 386390.

3-Berdy J. Microorganisms producing antibiotics. In Sanchéz S, Demain AL. Antibiotics. Norfolk: CaisterAcademin Press; 2015. p. 49-64.

4-Bevan P, Ryder H. Show I. Identify small molecular lead compounds: The screening approach to drug discovery. Trends Biotechnol. 1995; 113: 115-121.

5-Achkar JM, Fries BC. Candida infections of the genitourinary tract. ClinMicrobiol Rev. 2010; 23: 253-273.

6-Sangamwar AT, Deshpande UD, Pekamwar SS. Antifungals: Need to search for a new molecular target. Indian J. Pharm. Sci. 2008; 70 (4): 423430.

7-Scorzoni L, Benaducci T, Almeida AMF, Silva DHS, Bolzani VDS, Gianinni MJSM. The use of standard methodology for determination of antifungal activity of natural products against medical yeasts Candida sp. and Cryptococcus sp. Brazilian J. Microbiol. 2007; 38: 391-397.

8-Moosa MY, Sobel JD, Elhalis H, Du W, Akins RA. Fungicidal activity of fluconazole against Candida albicans in a synthetic vaginasimulative medium. Antimicrob. Agents Chemother. 2004; 48: 161-167.

9-Barrow JJ, Oleynek HH, Marinelli V, Sun HH, Kaplita P, Sedlock DM et al. Antimycins, inhibitors of ATP-citrate lyase, from a Streptomyces sp. J. Antibiot. 1997; 50 (9): 729733.

10- Gräfe U. Biochemie der Antibiotika. Heidelbers, Berlin, New York: AkademischerVerlag; 1992.

11- Xu LY, Quan XS, Wang C, Sheng HF, Zhou $\mathrm{GX}$, Lin BR et al. Antimycins $\mathrm{A}_{19}$ and $\mathrm{A}_{20}$, two new antimycins produced by marine actinomyceteStreptomyces antibioticus H74-18. J Antibiot. 2011; 64: 661-665.

12- Shiomi K, Hatae K, Hatano H, Matsumoto A, Takahashi Y, Jiang CL et al. A new antibiotic, Antimycin $\mathrm{A}_{9}$, produced by Streptomyces $\mathrm{sp}$. K01-0031. J. Antibiot. 2005; 58: 74-78.

13- Mendes TD, Borges WS, Rodrigues A, Solomon SE, Vieira PC, Duarte MCT et al. AntiCandida properties of Urauchimycins from actinobacteria associated with Trachymyrmex Ants. Biomed Res. Int. 2013; 2013: 1-8.

14- Garrity GM, Bell JA, Lilburn T. Bergey's Manual of Systematic Bacteriology. $2^{\text {nd }}$ edition. New York: Springer; 2005.

15- Korzeniewska E, Filipkowska Z, Gotkowska Plachta A., Janczukowicz W, Dixon B, 
Czulowska M. Determination of emitted airborne microorganisms from a BIO-PAK wastewater treatment plant. Wat. Res. 2009; 43: 2841-2851.

16- Větrovský T, Steffen KT, Baldrian P. Potential of cometabolic transformation of polysaccharides and lignin in lignocellulose by soil Actinobacteria. PloS ONE. 2014; 9(2): e89108.

17- Wink, J. Compendium of Actinobacteria Internet. 2009 cited 2016 Apr. 1. Available from: http://www.dsmz.de/bacterialdiversity/compendium-of-actinobacteria.html.

18- Cazin J, Wiemer DF, Howard JJ. Isolation, growth characteristics, and long-term storage of fungi cultivated by attine ants.App Env Micro. 1989; 55 (6): 1346-1350.

19- Wiegand I, Hilpert K, Hancock RE. Agar and broth dilution methods to determine the minimal inhibitory concentration (MIC) of antimicrobial substances. Nat Protoc. 2008; 3: 163-175.

20- Shirling EB, Gottlieb D. Methods for characterization of Streptomyces species. Int J SystBacteriol. 1966; 16 (3): 313-340.

21- Suter MA. Isolierung und Charakterisierung von melanin-negativenmutantenausStreptomyces glaucescens: thesis no. 6276. Switzerland: EidgenossischeTechnischeHochschule Zurich. 1978.

22- Kutzner HJ. The family Streptomycetaceae. In Starr MP, Stolp H, Trüpper HG, Balons A., Schlegel HG. The prokaryotes - A handbook on habitats, isolation and identification of bacteria. Berlin: Springer Verlag; 1981. p. 2028-2090.

23- Sambrook J. Molecular Cloning: A Laboratory Manual. $3^{\text {rd }}$ edition. New York: Cold Spring Harbor Laboratory Press; 2001.

24- Cook AE, Meyers PR. Rapid identification of filamentous actinomycetes to the genus level using genus-specific 16S rRNA gene restriction fragment patterns. Int J SystEvolMicrobiol. 2003; 53: 1907-1915.

25- Thompson JD, Higgins DG, Gibson TJ. CLUSTAL W: improving the sensitivity of progressive multiple sequence alignment through sequence weighting, position-specific gap penalties and weight matrix choice. Nucleic Acid Res. 1994; 22 (22): 4673-4680.

26- Hall TA.BioEdit: a user-friendly biological sequence alignment editor and analysis program for Windows 95/98/NT. Nucleic Acids Symp Ser. 1999;41: 95-98.

27- Felsenstein J. Evolutionary trees from DNA sequences: A maximum likelihood approach. $J$ MolEvol. 1981; 17: 368-376.

28- Guindon S, Gascuel O. A simple, fast and accurate algorithm to estimate large phylogenies by maximum likelihood. Syst Biol. 2003; 52: 696-704.
29- Subramanioin LJ, Zakaria Z, Chen Y, Lau YL, Latha LY, Shin LN et al. Bioassay-directed isolation of active compounds with antiyeast activity from a Cassia fistula seed extract. $J$ Molecules. 2011; 16: 7583-7592.

30- Imamura N, Nishijima M, Adachi K, Sano H. Novel antimycin antibiotics, urauchimycins A and B, produced by marine actinomycete. $J$ Antibiot. 1993; 46(2): 241-246.

31- Yao, CBF, Schiebel M, Helmke E, Anke H, Laatsch H. Prefluostatin and new urauchimycinderivates produced by Streptomycete isolates. Z Naturforsch. 2006; 61b: 320-325.

32- Hayashi K, Nozaki H. Kitamycins, new antimycin antibiotics produced by Streptomyces sp. J Antibiot. 1999; 52: 325-328.

33- Wood SA, Kirby BM, Goodwin CM, Le Roes M, Meyers PR. PCR screening reveals unexpected antibiotic biosynthetic potential in Amycolatopsis sp. strain UM16. J ApplMicrobiol. 2007; 102: 245-253.

34- Zhi SX, Li WJ, Stackebrand E. An updade of the structure and 16S rRNA gene sequence-based definition of higher ranks of the class Actinobacteria, with the proposal of two suborders and four new families and emended descreiptions of the existing higher taxa. Int $J$ SystEvolMicrobiol. 2009; 59: 589-608.

35- Suneetha V, Karthick R, Prathusha K. Isolation and identification of Streptomyces ST1 and ST2 strains from Tsunami affected soils: Morphological and biochemical studies. $J$ Oceanogr Mar Sci. 2011; 2(4): 96-101.

36- Tresner HD, Hayes JA, Backus EJ. Differential tolerance of streptomycetes to sodium chloride as a taxonomic aid. ApplMicrobiol. 1968; 16: 11341136.

37- Sugawara K, Tomita K, Kozlowski MR, Sawada Y. Compounds produced by a strain of Streptomyces exfoliates. Patent no: US5332574 A Internet. 1994 cited 2016 Jan 14. Available from.https://www.google.com/patents/US533257 4.

38- Mohan R, Vijayakumar R. Isolation and characterization of marine antagonistic actinomycetes from west coast of India. Biol Med. 2007; 15(1): 13-19.

39- Humble MW, King A, Phillips I. API ZYM: a simple rapid system for the detection of bacterial enzymes. J ClinPathol. 1977; 30: 275-277.

40- Vítězová M. 2013. Characterisation of actinomycetes community from the heavy metals-pollute soil. Actauniv.agri. etsilvi. Mende. Brun. 2013; 61: 1471-1478.

Received: January 15, 2016 Accepted: May11, 2016 